\title{
USE OF MINIMUM TILLAGE IN SUNFLOWER GROWING UNDER STEPPE CONDITIONS OF SOUTHERN UKRAINE
}

\author{
Aksyonov, I.
}

Institute of Oilseed Crops, Ukrainian Academy of Agricultural Sciences, Vesennyaya, 1, Solnecniy, 70417 Zaporozhie, Ukraine.

Received: February 25, 2010

Accepted: August 10, 2010

\section{SUMMARY}

We studied minimum tillage methods suitable for sunflower growing. By selecting and combining appropriate methods, we simultaneously increased the competitiveness of sunflower agrocoenoces against weeds and sunflower yield. Sunflower sowing after wheat at a row spacing of $22.8 \mathrm{~cm}$ increased the yield of the hybrid Zaporozhskiy 14 by 0.07-0.19 t/ha after regular plowing and by $0.10-0.12 \mathrm{t} / \mathrm{ha}$ after anti-erosion tillage as compared with the sowing at a row spacing of $70 \mathrm{~cm}$.

Key words: sunflower, soil tillage, distance between rows, herbicides, productivity

\section{INTRODUCTION}

The sunflower (Helianthus annuus L.) is an important oil crop in Ukraine. Presently, it is grown there at more than 4 million hectares. In the conditions of economic crisis and the sowing area reduction of field crops in the rotation, sunflower cultivation determines the financial and economic position of many agricultural enterprises in Ukraine.

Sunflower cultivation efficiency is determined by a correct selection of agrotechnical measures applied from soil tillage after previous crop to sunflower sowing.

Agrotechnical measures should ensure a production with minimum expenses and maximum plant productivity. Unfortunately, here we face a number of problems. The rise of the total volume of sunflower production has resulted from the increase of the sunflower acreage from 2 million to 4 million hectares. At the same time, the average yield of sunflower remained low- 1.2-1.3 t/ha - while the cultivation expenses remained high.

* Corresponding author: Phone: +30-61-223-99-66; Phone/Fax: +30-61-223-99-50; e-mail: aksyonov-igor@rambler.ru 
Under such circumstances, cultivation expenses may be reduced only by employing minimum tillage. Minimum tillage is based on the use of anti-erosion agricultural implements and reduction of the number of agrotechnical measures applied (Kiryushin, 2006). Minimum tillage offers the following advantages: prevention of soil erosion by wind, reduction of soil moisture evaporation rate and reduction of energy consumption for crop cultivation (Vasiliev, 1990; Kiver, 1988).

However, some authors claim that minimum tillage increases the rate of weed infestation in production fields, deteriorating the physical and mechanical soil properties and reducing crop yields. In dry years, minimum tillage applied in Ukraine steppe prevents sunflower hybrids and varieties from achieving a yield level expected on the basis of their biological characteristics, genetic yield potential and water-use level (Egorin and Bortsova, 1991; Nikolaeva and Ladan, 1998; Shcherbakov and Volodin, 1993).

Best effects are achieved when complete agrotechnical operations are performed. They form an optimal arable layer, which stimulates plant growth and development and protects soil against erosion (Rymar et al., 2005). However, this solution is not viable economically.

Therefore, the purpose of this investigation was to define a minimum technology for sunflower cultivation, to determine a relationship between weed infestation rate and sunflower yield, and to evaluate the effect of minimal agrotechnical practices on sunflower yield performance.

\section{MATERIAL AND METHODS}

Experiments have been conducted at Institute of Oilseed Crops (Zaporozhie, Ukraine). The soil in the experiment plots was the black steppe soil, with the humus content in the soil layer $0-30 \mathrm{~cm}$ of $3.4-3.6 \%$ and the $\mathrm{pH}$ of the soil solution from 6.8 to 7.0 .

Sunflower was grown in 12 plots. It was preceded by winter wheat. After winter wheat harvest, the field was prepared by the system of improved land cultivation (Table 1).

Table 1: Agrotechnical measures in the system of improved land cultivation

\begin{tabular}{lcc}
\hline Agrotechnical measure & Tillage depth, cm & Date \\
\hline $\begin{array}{l}\text { Stubble scraping after winter } \\
\text { wheat harvest with LDG-10 }\end{array}$ & $6-8$ & After winter wheat harvest \\
$\begin{array}{l}\text { Soil tillage with KPE-3.8, } \\
\text { an anti-erosion cultivator }\end{array}$ & $10-12$ & After weed development \\
Disc harrowing with BDT-7 & $8-10$ & After weed development \\
\hline
\end{tabular}

The primary tillage was performed in late September - early October. Two methods of tillage were employed - conventional plowing (control) and anti-erosion tillage. The depth of primary tillage was $25-27 \mathrm{~cm}$. Two plow types were used: PN-4- 
35, a conventional moldboard plow, and PRPV-5-50, a chisel-plow for anti-erosion tillage. In the latter case, the soil was leveled with a cultivator KPS-4.0.

The following spring, seedbed preparation was performed, which included soil tillage with a cultivator to a depth of $6-8 \mathrm{~cm}$.

The herbicide Treflan (5 l/ha) was applied after soil cultivation and directly before sunflower sowing. The herbicide Roundup ( $2.5 \mathrm{l} / \mathrm{ha}$ ) was applied before sunflower sowing. In the variants with Treflan application, the sunflower hybrid Zaporozhskiy 14 was sown when soil temperature at the depth of 6-8 $\mathrm{cm}$ reached 8$10^{\circ} \mathrm{C}$. In the variants with Roundup application, sunflower sowing was performed 12 days after herbicide application.

The depth of sowing was $6-8 \mathrm{~cm}$. Two row spacings were employed, $70 \mathrm{~cm}$ (control) and $22.8 \mathrm{~cm}$. The sowing in the row spacing of $70 \mathrm{~cm}$ was done with a seeder "Multicorn" and in the row spacing of $22.8 \mathrm{~cm}$ with a grain stubble seeder. The seeder blades were equipped with wing shares.

In the case of row spacing of $70 \mathrm{~cm}$ and Treflan application, the agrotechnical measures of crop care included two between-row cultivations. In the case of the same row spacing and Roundup application, one harrowing after crop emergence and two between-row cultivations were performed. In the case of row spacing of $22.8 \mathrm{~cm}$, one harrowing was performed after sunflower emergence.

The above agrotechnical measures were applied in both plowing variants, conventional plowing and anti-erosion tillage.

Each treatment in the experiment was performed in four replications. The experiment was harvested with a combine harvester Sampo 500.

Observations were executed in accordance with generally accepted methods, on 20 plants from inner rows of two non-adjacent replicates in each variant. The obtained results were analyzed by MSTAT, and their means were compared by Tukey's multiple comparison test at $5 \%$ level.

\section{RESULTS AND DISCUSSION}

Before Roundup application and sunflower sowing, weed density was lower in the control than in the variant of anti-erosion tillage. In the variant of conventional plowing, weed density was 10.5 weed plants $/ \mathrm{m}^{2}$, of which $61.9 \%$ were early-spring weeds (Table 2). In the variant of anti-erosion tillage, weed density was 77.5 weed plants $/ \mathrm{m}^{2}$, of which $61.0 \%$ were late-spring weeds.

Table 2: Weed density following the two methods of primary soil tillage

\begin{tabular}{lcccc}
\hline \multirow{2}{*}{ Weed } & \multicolumn{2}{c}{ Conventional plowing } & \multicolumn{2}{c}{ Anti-erosion tillage(PRPV-5-50) } \\
\cline { 2 - 5 } & $\begin{array}{c}\text { Quantity of weeds } \\
\text { weeds } / \mathrm{m}^{2}\end{array}$ & $\begin{array}{c}\text { Ratio } \\
\%\end{array}$ & $\begin{array}{c}\text { Quantity of weeds } \\
\text { weeds } / \mathrm{m}^{2}\end{array}$ & $\begin{array}{c}\text { Ratio } \\
\%\end{array}$ \\
\hline Parasitic weeds & 0.2 & 2.4 & 0.5 & 0.6 \\
Rootstock weeds & - & - & - & - \\
Early spring & 6.5 & 61.9 & 29.7 & 38.4 \\
Late spring & 3.8 & 35.7 & 47.3 & 61.0 \\
Total & 10.5 & 100.0 & 77.5 & 100.0 \\
\hline
\end{tabular}


The method of improved winter plowing performed in the summer-fall period ensured an effective control of the parasitic and rootstock weeds.

In the case of the anti-erosion tillage and high weed infestation, the application of Roundup before sunflower sowings was more effective than the application of Treflan.

When the pre-sowing treatment consisted of one soil cultivation, the application of Roundup before sunflower sowing reduced the weed density at flowering and before the harvest of Zaporozhskiy 14 by $19.5-30.2 \%$ in the sunflower field with the row spacing of $70 \mathrm{~cm}$, and by $24.8-30.4 \%$ in the field with the row spacing of 22.8 cm (Table 2).

The lowest air-dry weight of weeds before sunflower harvest $\left(24.32-43.28 \mathrm{~g} / \mathrm{m}^{2}\right)$ was registered in the variant of conventional plowing.

When a moldboard plow was used (PRPV-5-50) the air-dry weight of weeds ranged from 37.12 to $78.04 \mathrm{~g} / \mathrm{m}^{2}$. Maximum air-dry weights of weeds after conventional plowing (32.14-43.28 $\mathrm{g} / \mathrm{m}^{2}$ ) and anti-erosion tillage $\left(52.11-78.04 \mathrm{~g} / \mathrm{m}^{2}\right)$ were in the control, when Treflan was applied before pre-sowing cultivation. After the application of Roundup, decreases in air-dry weight of weeds before sunflower harvest were observed in both crop stands, those with the row spacings of $70 \mathrm{~cm}$ and $22.8 \mathrm{~cm}$, regardless of the method of primary tillage.

Table 3: Effect of soil cultivation methods on weed density in sunflower crop

\begin{tabular}{|c|c|c|c|c|c|}
\hline \multirow[b]{2}{*}{ Tillage method } & \multirow{2}{*}{$\begin{array}{l}\text { Herbicide } \\
\text { application }\end{array}$} & \multirow{2}{*}{$\begin{array}{c}\text { Row } \\
\text { spacing, } \\
\text { cm }\end{array}$} & \multirow{2}{*}{$\begin{array}{l}\text { No. of weeds } \\
\text { per } \mathrm{m}^{2} \\
\text { at flowering }\end{array}$} & \multicolumn{2}{|c|}{ Before sunflower harvest } \\
\hline & & & & $\begin{array}{l}\text { No. of weeds } \\
\text { per } \mathrm{m}^{2}\end{array}$ & $\begin{array}{c}\text { Air-dry mass of } \\
\text { weeds, } \mathrm{g} / \mathrm{m}^{2}\end{array}$ \\
\hline \multirow{4}{*}{$\begin{array}{l}\text { Conventional } \\
\text { plowing } \\
\text { (control) }\end{array}$} & \multirow{2}{*}{ Treflan (control) } & 70 (control) & 10.0 & 13.0 & 32.14 \\
\hline & & 22.8 & 14.5 & 17.5 & 43.28 \\
\hline & \multirow{2}{*}{ Roundup } & 70 & 9.8 & 9.8 & 24.32 \\
\hline & & 22.8 & 13.8 & 15.3 & 40.31 \\
\hline \multirow{4}{*}{$\begin{array}{l}\text { Antierosive } \\
\text { tillage } \\
\text { (PRPV-5-50) }\end{array}$} & \multirow{2}{*}{ Treflan } & 70 & 18.8 & 21.5 & 52.11 \\
\hline & & 22.8 & 28.0 & 31.0 & 78.04 \\
\hline & \multirow{2}{*}{ Roundup } & 70 & 14.5 & 17.3 & 44.01 \\
\hline & & 22.8 & 19.5 & 23.3 & 56.13 \\
\hline
\end{tabular}

In both variants of winter plowing, conventional plowing and anti-erosion tillage, weed density and weed air-dry weight were reduced more in the row spacing of $70 \mathrm{~cm}$ than $22.8 \mathrm{~cm}$. The former spacing received two between-row cultivations, the latter none. In the row spacing of $70 \mathrm{~cm}$, weed density before sunflower harvest was reduced to $4.2-5.5$ weeds $/ \mathrm{m}^{2}$ in the variant of conventional plowing and to 6.0-9.5 weeds $/ \mathrm{m}^{2}$ in the variant of anti-erosion tillage. The respective air-dry weights of weeds were 11.14 and $15.99 \mathrm{~g} / \mathrm{m}^{2}$.

The narrow row spacing provided an effective weed suppression on account of minimum soil operations, which has a number of advantages in the dry conditions of the southern steppe in Ukraine. Leaving the soil to rest for 20-25 days before 
sunflower sowing tended to reduce losses of soil moisture by evaporation. Besides, the early-spring soil cultivation provoked an early occurrence of weeds in the presowing period, allowing maximum weed control before sunflower sowing and application of Roundup, a continuous-action herbicide that controlled parasitic weeds.

The harrowing after sunflower emergence in the variant of row spacing of 22.8 $\mathrm{cm}$ resulted in the air-dry weight of weeds of $43.28-40.31 \mathrm{~g} / \mathrm{m}^{2}$ in the variants of conventional plowing and $78.04-56.13 \mathrm{~g} / \mathrm{m}^{2}$ in the variants of anti-erosion tillage (PRPV-5-50).

Productivity level of the sunflower hybrid Zaporozhskiy 14 was influenced by the method of primary soil tillage and row spacing.

The hybrid had a higher yield with the row spacing of $22.8 \mathrm{~cm}$ than $70 \mathrm{~cm}$. Sunflower growing in the row spacing of $22.8 \mathrm{~cm}$, where minimum tillage was followed by pre-seeding cultivation, where sowing was performed with a grain stubble seeder and where between-row cultivation was excluded, brought a yield increase of 0.070.19 t/ha (Table 4).

Table 4: Effect of soil cultivation method on the productivity of the sunflower hybrid Zaporozhskiy 14

\begin{tabular}{|c|c|c|c|c|c|c|}
\hline \multirow{2}{*}{$\begin{array}{l}\text { Method of } \\
\text { soil tillage }\end{array}$} & \multirow{2}{*}{$\begin{array}{l}\text { Herbicide } \\
\text { application }\end{array}$} & $\begin{array}{c}\text { Row } \\
\text { spacing }\end{array}$ & $\begin{array}{c}\text { Head } \\
\text { diameter }\end{array}$ & $\begin{array}{c}\text { Sunflower } \\
\text { yield }\end{array}$ & $\begin{array}{c}\text { Weight of } \\
1000 \text { seeds }\end{array}$ & $\begin{array}{l}\text { Oil content } \\
\text { in seeds }\end{array}$ \\
\hline & & $\mathrm{cm}$ & $\mathrm{cm}$ & t/ha & $g$ & $\%$ \\
\hline \multirow{4}{*}{$\begin{array}{l}\text { Conventional } \\
\text { plowing } \\
\text { (control) }\end{array}$} & \multirow{2}{*}{ Treflan (control) } & 70 (control) & 18.0 & 2.21 & 58.1 & 51.2 \\
\hline & & 22.8 & 18.6 & 2.28 & 59.0 & 52.2 \\
\hline & \multirow{2}{*}{ Roundup } & 70 & 18.2 & 2.14 & 58.2 & 51.0 \\
\hline & & 22.8 & 18.7 & 2.33 & 59.8 & 51.5 \\
\hline \multirow{4}{*}{$\begin{array}{l}\text { Anti-erosion } \\
\text { tillage } \\
\text { (PRPV-5-50) }\end{array}$} & \multirow{2}{*}{ Treflan } & 70 & 17.5 & 2.08 & 55.2 & 50.7 \\
\hline & & 22.8 & 18.1 & 2.19 & 56.6 & 52.3 \\
\hline & \multirow{2}{*}{ Roundup } & 70 & 17.9 & 2.04 & 55.0 & 50.7 \\
\hline & & 22.8 & 18.2 & 2.16 & 56.7 & 50.4 \\
\hline
\end{tabular}

In the variants of anti-erosion tillage, the yield of the hybrid Zaporozhskiy 14 was reduced by $0.17 \mathrm{t} / \mathrm{ha}$ in the plots with the row spacing of $70 \mathrm{~cm}$ and by 0.09 $0.17 \mathrm{t} / \mathrm{ha}$ in the plots with the row spacing of $22.8 \mathrm{~cm}$. Also, the application of chizeling, where the topsoil is not turned, led to reductions in the weight of 1000 seeds and oil content in seed by $2.9-3.2 \mathrm{~g}$ and $0.3-0.5 \%$, respectively, in the row spacing of $70 \mathrm{~cm}$, on by $2.4-3.1 \mathrm{~g}$ and $1.1 \%$, respectively, in the row spacing of 22.8 $\mathrm{cm}$. The increases in the density of weeds and their air-dry weight in the row spacing of $22.8 \mathrm{~cm}$ was not a limiting factor for sunflower productivity either in the variant of moldboard plowing or chizeling. The hybrid Zaporozhskiy 14 produced maximum yields in the variants of moldboard plowing and chizeling in spite of the respective maximum air-dry weights of weeds of $43.28-40.31 \mathrm{~g} / \mathrm{m}^{2}$ and $78.04-56.13$ $\mathrm{g} / \mathrm{m}^{2}$, respectively. The maximum air-dry weight of weeds, $78.04-56.13 \mathrm{~g} / \mathrm{m}^{2}$, in the variant of anti-erosion tillage and the row spacing of $22.8 \mathrm{~cm}$ allowed a yield formation at the level of 2.16-2.19 t/ha, similar to the yield in the control variants with the row spacing of $70 \mathrm{~cm}$ after conventional plowing (Figures 1 and 2). 


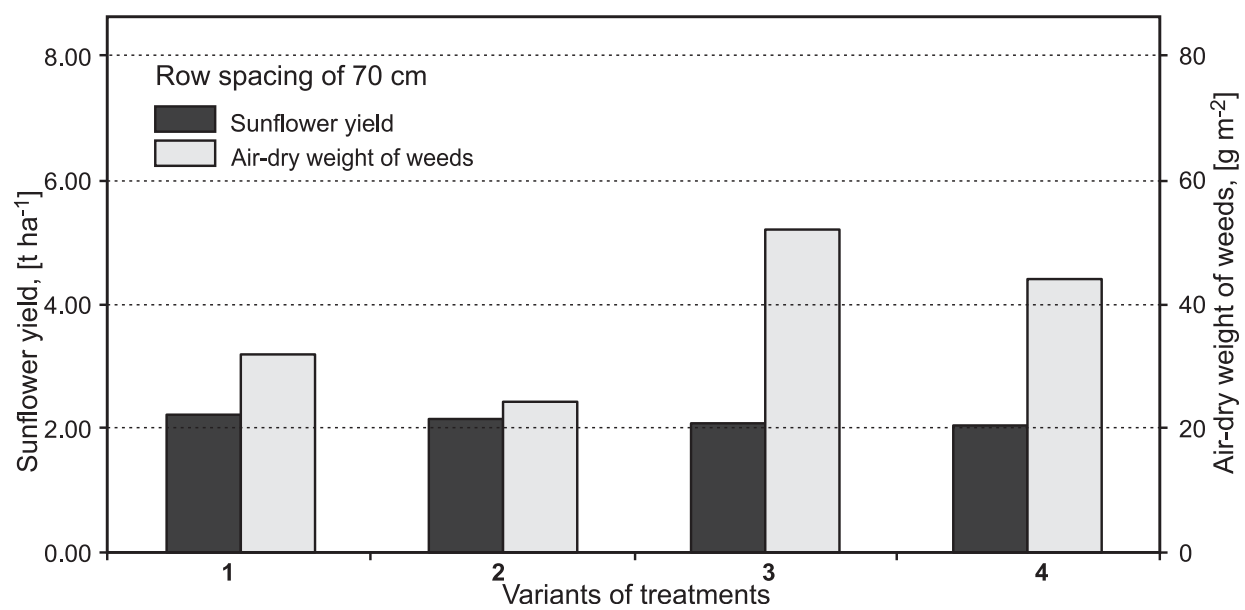

Figure 1: Yield of sunflower ( $t / h a)$ and air-dry weight of weeds $\left(\mathrm{g} / \mathrm{m}^{2}\right)$ in the row spacing of $70 \mathrm{~cm}$, in the variants:

1. Conventional plowing + Treflan; 2. Conventional plowing + Roundup;

3. Anti-erosion tillage + Treflan: 4. Anti-erosion tillage + Roundup.

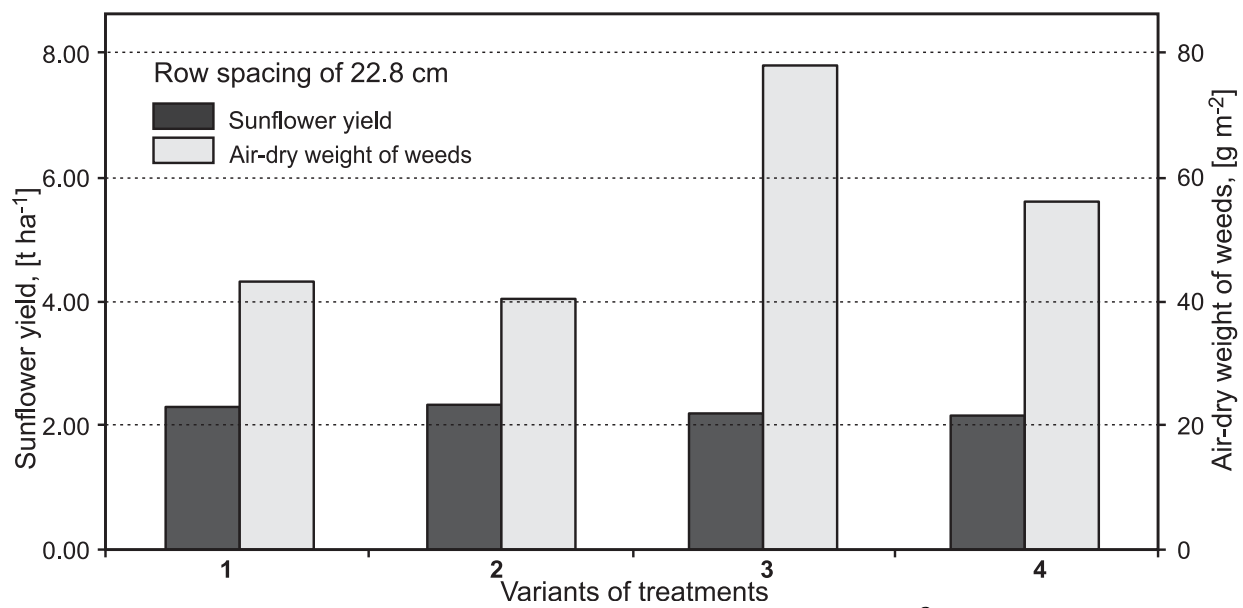

Figure 2: Yield of sunflower ( $t / \mathrm{ha}$ ) and air-dry weight of weeds $\left(\mathrm{g} / \mathrm{m}^{2}\right)$ in the row spacing of $22.8 \mathrm{~cm}$, in the variants:

1. Conventional plowing + Treflan; 2. Conventional plowing + Roundup;

3. Anti-erosion tillage + Treflan: 4. Anti-erosion tillage + Roundup.

Our results showed that the sunflower stand with the narrow row spacing of $22.8 \mathrm{~cm}$ had a high competitive capacity in relation to weeds. The analysis of the obtained data indicated that the structural change of the stand of the hybrid Zaporozhskiy 14, achieved by narrowing down the row spacing to $22.8 \mathrm{~cm}$, allowed to reach the highest possible productivity by the anti-erosion tillage performed with the implement PRPV-5-50. 


\section{CONCLUSIONS}

Minimum tillage of soil and substitution of a system of plant care practices applied after sunflower emergence with Roundup application before sunflower sowing did not seem to decrease the productivity of the hybrid Zaporozhye 14. The optimized system of agricultural practices involving a minimized anti-erosion tillage, herbicide application, and the sowing at a row spacing of $22.8 \mathrm{~cm}$, effectively solved a problem of increased weed competition and brought the highest possible yield of sunflower with the economic input in the production still within a viable bracket.

\section{REFERENCES}

Egorin, A.I. and Bortsova, A.V., 1991. The sunflower cultivation in eastern Kazakhstan. Technical Crops 2: 16-17.

Kiryushin, V.A., 2005. Minimization of the soil tillage: discussion sums. Husbandry 4: 28-30. Kiver, V.Ph., 1988. The energy-saving technology of the maize cultivation at the irrigated ground, Harvest, Kiev, pp. 1-126.

Nikolaeva, N.G. and Ladan, S.S., 1998. The harmfulness of weeds. Husbandry 2: 20-22.

Rymar, V.T., Turusov, V.I. and Romantsov, Yu.Ph., 2005. The estimate of different technologies of the sunflower cultivation. Husbandry 5: 20-21.

Shcherbakov, A.P. and Volodin, V.M., 1993. The agroecological principles of husbandry, Science, Moscow, pp. 12-13.

Vasiliev, D.S., 1990. Sunflower. Agropromizdat, Moscow, pp. 4-102. 
